\title{
CORPORATION AND INSTITUTIONAL MEMBERS
}

\section{SUSTAINING MEMBERS}

Ball Aerospace \& Technologies Corporation

Boeing Company

ITT Corporation

Lockheed Martin Corporation

Northrop Grumman Space Technology

Raytheon Company

University Corporation for Atmospheric Research

Vaisala Inc.

\section{REGULAR MEMBERS}

3TIER Environmental Forecast Group, Inc.

Aanderaa Instruments Inc.

AccuWeather, Inc.

ADNET Systems Inc.

Aerospace \& Marine International Corporation

AirDat LLC

All Weather, Inc.

Anasphere Inc.

Atmospheric and Environmental Research Inc.

Atmospheric Technology Services Company LLC

AWS Convergence Technologies, Inc.

Baron Services Inc.

BBC Weather Center

Belfort Instrument Company

Botswana Meteorological Service

Bristol Industrial Research Association

Campbell Scientific Inc.

Climatronics Corporation

CLS America, Inc.

Coastal Environmental Systems

Computer Sciences Corporation

CSIRO Atmospheric Research

Davis Instruments Corporation

DeTect Inc.

EKO Instruments Company Ltd.

Enterprise Electronics Corporation

Florida State University, Department of Meteorology

Global Hydrology and Climate Center

Harris Corporation

Indian National Center for Medium Range Weather Forecasting Indian Space Research Organization, Radar Development Unit

International Met Systems

IPS MeteoStar

Jenoptic, Laser, Optik, Systeme GmbH

Jeppesen

Kipp \& Zonen USA Inc.

Meteorlogix LLC

MeteoSwiss

Met One Instruments Inc.

MSI Guaranteed Weather, LLC

Murray \& Trettel, Inc., Consulting Meteorologists

Netherlands Royal Meteorological Institute

Noblis, Inc.

Pelmorex Media Inc.

Planalytics Inc.

QSS Group, Inc.
Radiometrics Corporation

R. M. Young Company

Science Applications International Corporation

Scintec AG

SeaSpace Corporation

SGT, Inc.

Sonalysts Inc.

Unisys Corporation

University of Alabama in Huntsville, Earth System Science Center

University of Wisconsin-Madison, Space Science and Engineering Center

U.S. Department of Energy, Office of Science

U.S. Navy Meteorology and Oceanography Command

Vieux, Inc.

Weather Central Inc.

Weather Decision Technologies

Weather Channel

WeatherFlow Inc.

Weather Modification Inc.

Weathernews Americas Inc.

Weather Services International, Inc.

WindLogics Inc.

Wyle Information Systems

\section{SMALL BUSINESS MEMBERS}

Atmospheric Systems Corporation

Climadata Corporation

Geonor Inc.

National Council of Industrial Meteorologists

National Weather Service Employees Organization

Planetary Data Inc.

Remtech Inc

Sailing Weather Services

Sky Power International, LLC

Tempest Tours Inc.

Yankee Environmental Systems, Inc.

\section{PUBLICATIONS MEMBERS}

Abdus Salam International Centre for Theoretical Physics Aerospace Corporation Library

Australia Bureau of Meteorology, National Meteorological Library

Austria Central Institute of Meteorology and Geodynamics

Brock University Library

California Air Resources Board

Colorado State University Libraries

Columbia University, Lamont-Doherty Geological Observatory Geoscience Library

Creighton University Reinert/Alumni Memorial Library

Dartmouth College Baker Library

Desert Research Institute

Embry Riddle Aeronautical University

Environment Canada Library, Downsview

European Organisation for the Exploitation of Meteorological Satellites, Library

Finnish Meteorological Institute Library 


\section{CORPORATION AND INSTITUTIONAL MEMBERS}

Florida Institute of Technology Evans Library

Florida International University Library

German State and University Library of Lower Saxony, Goettingen

German Weather Service

Harvard University, Blue Hill Meteorological Observatory Library

Hong Kong Observatory Library

Indiana University Library

Indian Institute of Tropical Meteorology

Institute of Global Environment and Society

Irish Meteorological Service

Italian Regional Agency for the Protection of the AtmosphereFriuli, Venice, Julia

Kean University Geology and Meteorology Department

Los Alamos National Laboratory

Lyndon State College Samuel Read Hall Library

Marine Biological Laboratory/Woods Hole Oceanographic Institution, Library

Maryland Department of the Environment

Massachusetts Institute of Technology, Lincoln Laboratory

Météo-France

Millersville University, Department of Earth Sciences

National Weather Center Library

Naval Postgraduate School, Dudley Knox Library

New York University, Courant Institute Library

New Zealand Meteorological Service Ltd.

New Zealand National Institute of Water and Atmospheric Research, Wellington Library

NOAA Atlantic Oceanographic Meteorological Laboratory Library

NOAA Central Library

NOAA Earth System Research Laboratory, Library

NOAA Great Lakes Environmental Research Laboratory, Library

NOAA Library Seattle

NOAA National Climatic Data Center

North Carolina State University Libraries

Norwegian Meteorological Institute

Pennsylvania State University, Paterno Library

Purdue University Libraries

Republic of China Civil Aeronautics Administration

Republic of Korea Air Force, Headquarters

Scripps Institution of Oceanography Library

South African Weather Service

Swedish Meteorological and Hydrological Library

U.K. National Meteorological Library

University College Dublin

University of Copenhagen, Geophysical Institute

University of Colorado Libraries

University of Delaware Library

University of Frankfurt Library

University of Hawaii at Manoa, Library

University of Illinois, Department of Atmospheric Sciences

University of Innsbruck, Institute of Meteorology and Geophysics

University of Maryland, Department of Meteorology

University of Melbourne, Baillieu Library

University of New South Wales Library

University of North Carolina, Ramsey Library

University of North Dakota, Chester Fritz Library

University of Northern Colorado, Michener Library

University of Oklahoma, Department of Meteorology

University of Quebec at Montreal, Canadian Regional Climate Modelling Research Group

University of Rhode Island, Pell Marine Science Library

University of Versailles, Pierre Simon Laplace Institute

University of Washington Libraries

U.S. Air Force, 335 TRS/UOAA, Training Development

U.S. Air Force Air War College Center for Strategy and Technology

U.S. Air Force Weather Agency Technical Library

U.S. Air Force Weather Agency, Headquarters

U.S. Army Corps of Engineers Library, Vicksburg

U.S. Environmental Protection Agency Library

U.S. Navy Maritime Forecast Center/Joint Typhoon Warning Center, Pearl Harbor

Weather Predict Consulting, Inc.

Yale University, Geology Library

Weizmann Institute of Science, Central Library

Color indicates new or reinstated member

\section{Mid-Latitude \\ Weather Systems \\ by T.N. Carlson}

Mid-Latitude Weather Systems is the first text to make extensive use of conventional weather charts and equations to fully illustrate the behavior and evolution of weather

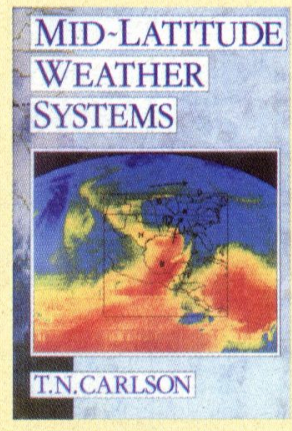
patterns.

Presenting a fusion between the mathematical and descriptive fields of meteorology and integrated coverage of synoptic and dynamic approaches, Mid-Latitude Weather Systems provides students with an invaluable course text and reference source to gain an unclouded appreciation of the underlying processes and behavior of mid-latitude weather patterns.

Mid-Latitude Weather Systems is available for \$52/list, \$42/AMS members, or $\$ 32 /$ students, by sending prepaid orders to: Order Department, AMS, 45 Beacon Street, Boston, MA 02108-3693. Please make checks payable to the American Meteorological Society, or call 617-227-2425 to order by phone (Mastercard, VISA, and American Express accepted). 


\section{FELLOWSHIP AND SCHOLARSHIP SPONSORS}

\section{FELLOWSHIPS}

AMS 21st Century Campaign

ITT $^{*}$

Lockheed Martin Corporation*

NASA's Earth Science Enterprise

NOAA's National Weather Service

NOAA's Climate Program Office

Raytheon Company*

SAIC, Earth Sciences Operation*

U.S. Department of Energy

\section{FRESHMAN AND UNDERGRADUATE SCHOLARSHIPS}

Baron Radar Services

Baron Advanced Meteorological Systems

The Boeing Company

CLS America, Inc.

Enterprise Electronics Corporation

Harris Corporation

Lockheed Martin MS2

NOAA's Office of the Federal Coordinator for Meteorology

Raytheon Information Services

R. M. Young Company

Science and Technology Corporation

Science Applications International Corporation (SAIC),

Center for Atmospheric Physics

Vaisala, Inc.

Jerome Namias Memorial Endowed Scholarship

Edgar J. Saltsman Endowed Scholarship

Bernard Vonnegut and Vincent Schaefer Endowed Scholarship

Percival D. Wark and Clara B. (Mackey) Wark Endowed

Scholarship

\section{MINORITY SCHOLARSHIPS}

AMS 21st Century Campaign

Baron Services

Earth Resources Technology, Inc.

The Weather Channel

Wyle Information Systems

\section{SENIOR SCHOLARSHIPS}

AMS 75th Anniversary Endowed Scholarship

Bhanwar Lal Bahethi Scholarship

Om and Saraswati Bahethi Scholarship

Saraswati (Sara) Bahethi Scholarship

Werner A. Baum Undergraduate Endowed Scholarship

Loren W. Crow Memorial Scholarship

Karen Hauschild Friday Endowed Scholarship

Bob Glahn Endowed Scholarship in Statistical Meteorology

Dr. Pedro Grau Undergraduate Scholarship

Richard and Helen Hagemeyer Scholarship

John R. Hope Endowed Scholarship in Atmospheric Sciences

David S. Johnson Endowed Scholarship

Larry R. Johnson Scholarship

Dr. Yoram Kaufman Scholarship

Carl W. Kreitzberg Endowed Scholarship

Max Mayfield Scholarship in Weather Forecasting

Ethan and Allan Murphy Endowed Memorial Scholarship

K. Vic Ooyama Endowed Scholarship

Howard T. Orville Endowed Scholarship in Meteorology

Paros-Digiquartz Scholarship

Guillermo Salazar Rodriguez Undergraduate Scholarship Mark J. Schroeder Endowed Scholarship in Meteorology

${ }^{\star}$ Corporate Patron

\section{AMERICAN METEOROLOGICAL SOCIETY}

\section{ONLINE MEMBERSHIP DIRECTORY}

This important professional and personal networking tool allows you to make contact with thousands of colleagues. The directory, which is searchable by last name, lists mailing addresses, telephone numbers, and electronic addresses of our members. It's easier than ever before to keep in touch.

The membership directory is password protected so that only our individual members may gain access. Visit the directory site to create your personalized user profile. Start taking advantage of this invaluable member resource today!

The online membership directory is located on the "Members Page," in the "Membership" section of the AMS Web site: www.ametsoc.org. 